\title{
Objects For Review / Materialer til anmeldelse
}

\section{Niels Erik Frederiksen}

\section{Ny plug-in til OJS - Objects For Review}

Til Open Journal Systems findes en plug-in, der gør det muligt at opsætte en speciel anmeldersektion på tidsskriftets hjemmeside, hvor tidsskriftets forfattere har mulighed for at se hvilke bøger og andre materialer tidsskriftet ønsker anmeldt, og hvor forfatterne kan tilmelde sig, hvis de ønsker at anmelde noget af det fremlagte materiale.

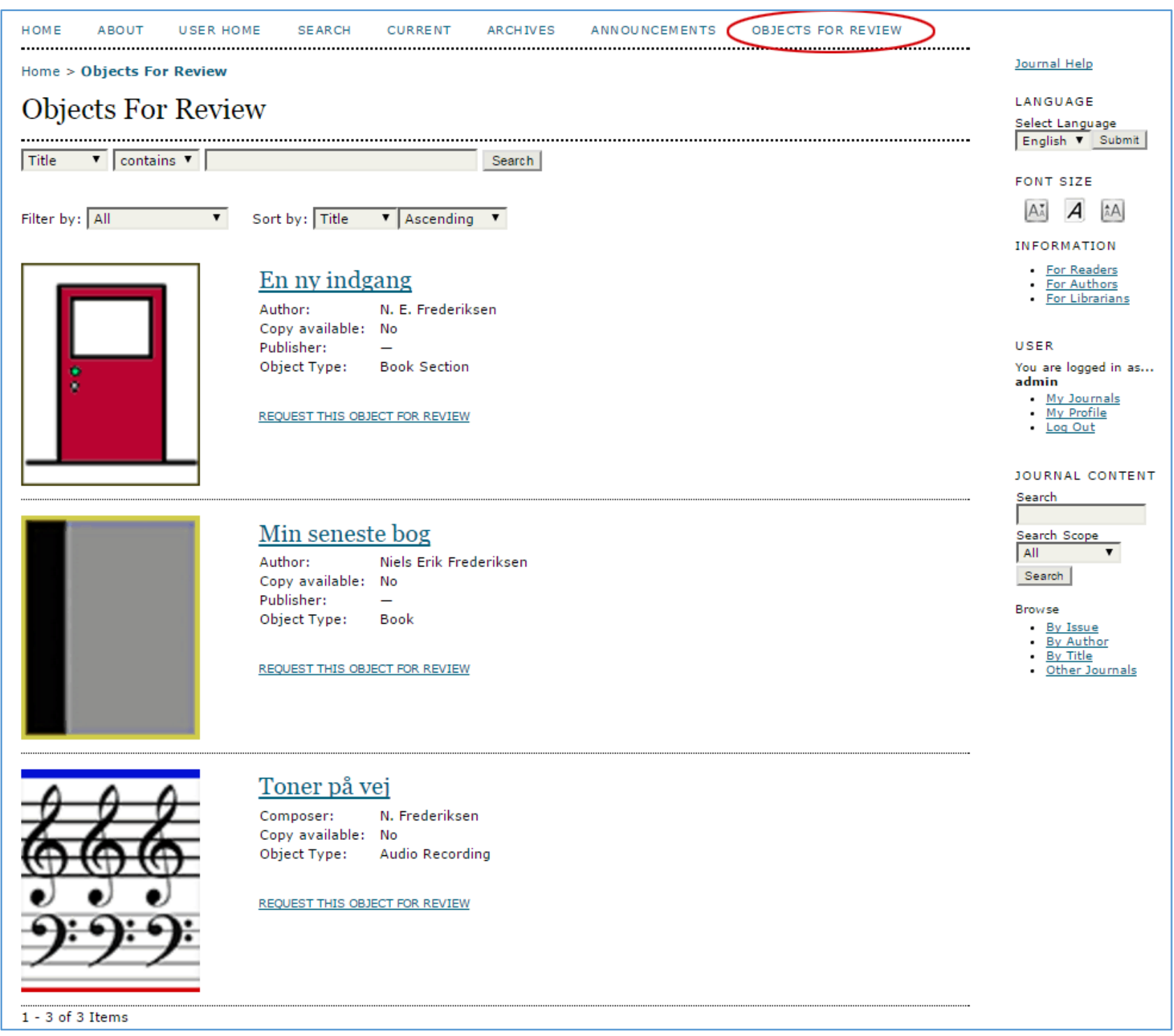

På siden 'Objects For Review' (Materialer til anmeldelse) ses det materiale tidsskriftsredaktionen ønsker anmeldt. Det kan være bøger, lydfiler, videoer og meget mere

I det følgende vises, hvordan plug-in'en sættes op, og hvordan det bruges i den redaktionelle proces. Plugin'en hedder 'Objects For Review' (Materialer til anmeldelse) og afløser den tidligere 'Books For Review' 
(Bøger til anmeldelse), der ikke længere opdateres. Eventuelle brugere af 'Books For Review' bør derfor nu skifte til den nye og bedre plug-in.

For at installere 'Objects For Review' skal du logge ind som Journal Manager (Tidsskriftschef) og vælge linket 'System Plugins'.

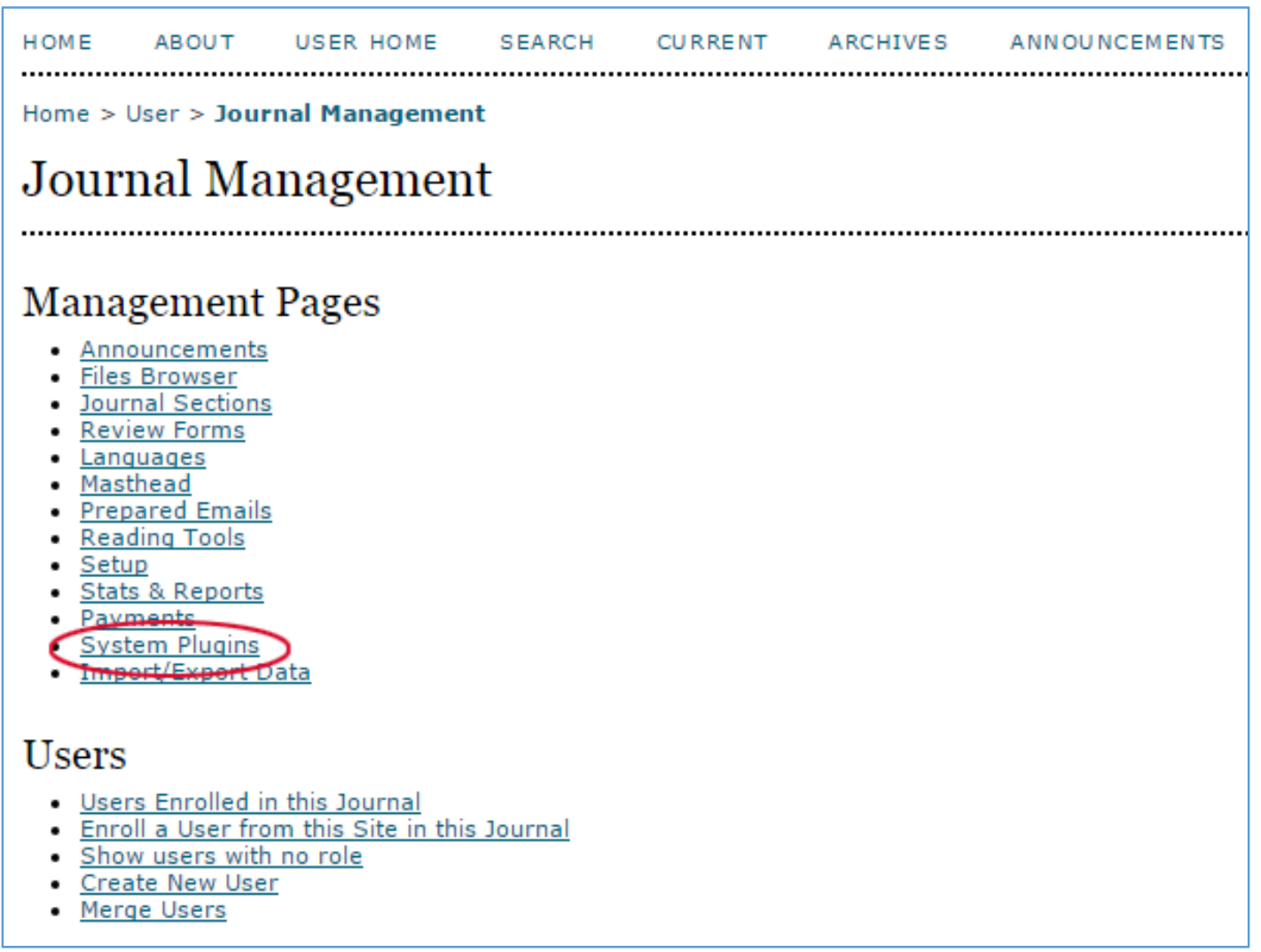

Herefter vælges 'Generic Plugins'

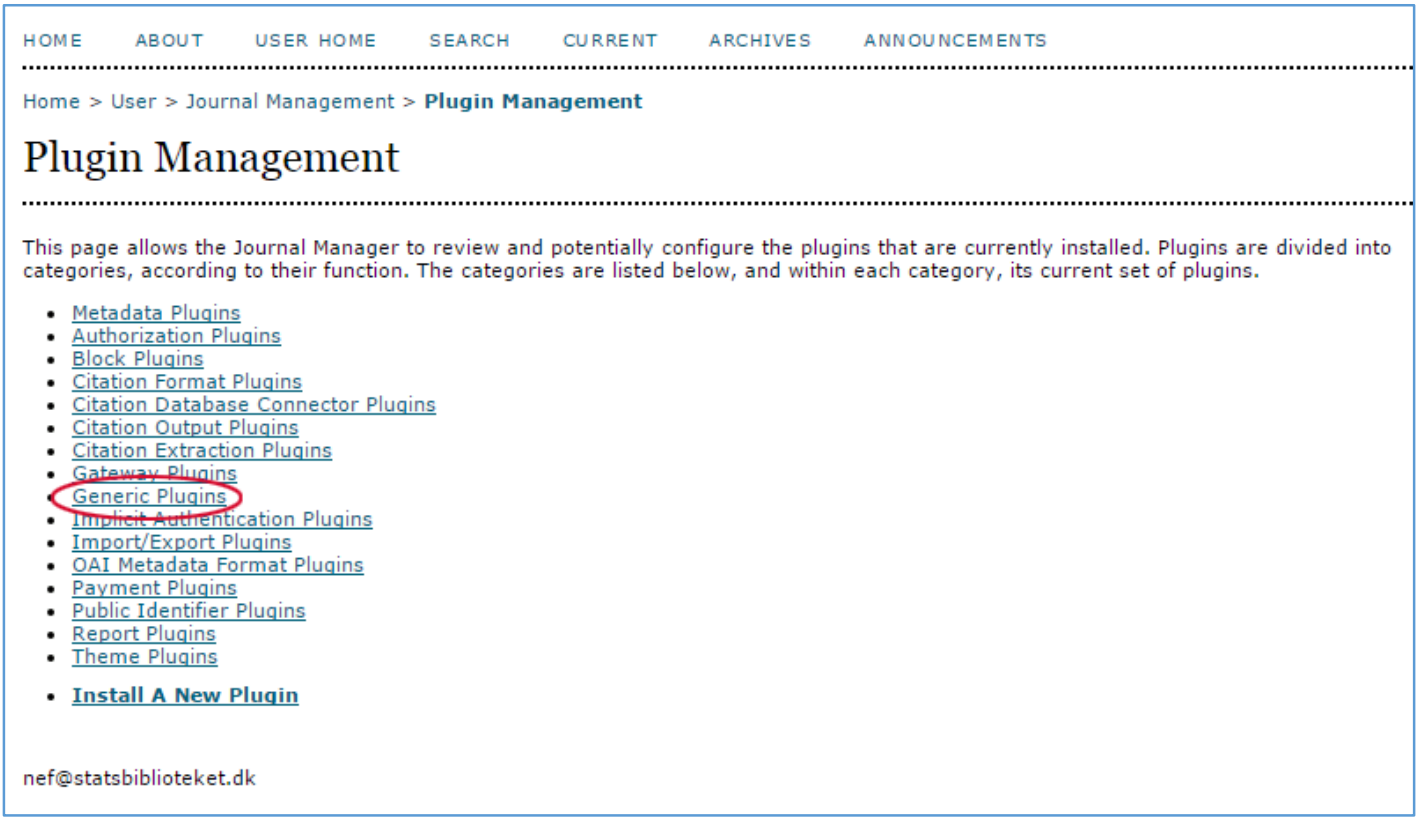


Lidt nede på den fremkomne side findes 'Objects For Review' (Materiale til anmeldelse). Her klikker du på linket 'Enable' (Aktivér).

Hermed er plug-in'en tilvalgt, og det er nu Editors (Redaktørens) opgave at sætte det yderligere op.

\section{- Backup Plugin}

This plugin generates a backup of the installation. ENABLE UPGRADE PLUGIN DELETE PLUGIN

\section{Objects For Review}

Solieitreviews for objects of interest. Manage review objects and the review process. ENABLE UPGRADE PLUGIN DELETE PLUGIN

\section{- Browse}

This plugin enables the browsing by sections and/or their identify types. ENABLE UPGRADE PLUGIN DELETE PLUGIN

Når du herefter logger dig ind som Editor (Redaktør), vil du nederst på startsiden finde to links, nemlig 'Review Object Types' (Materialetyper) og 'Object For Reviews' (Materialer til anmeldelse)

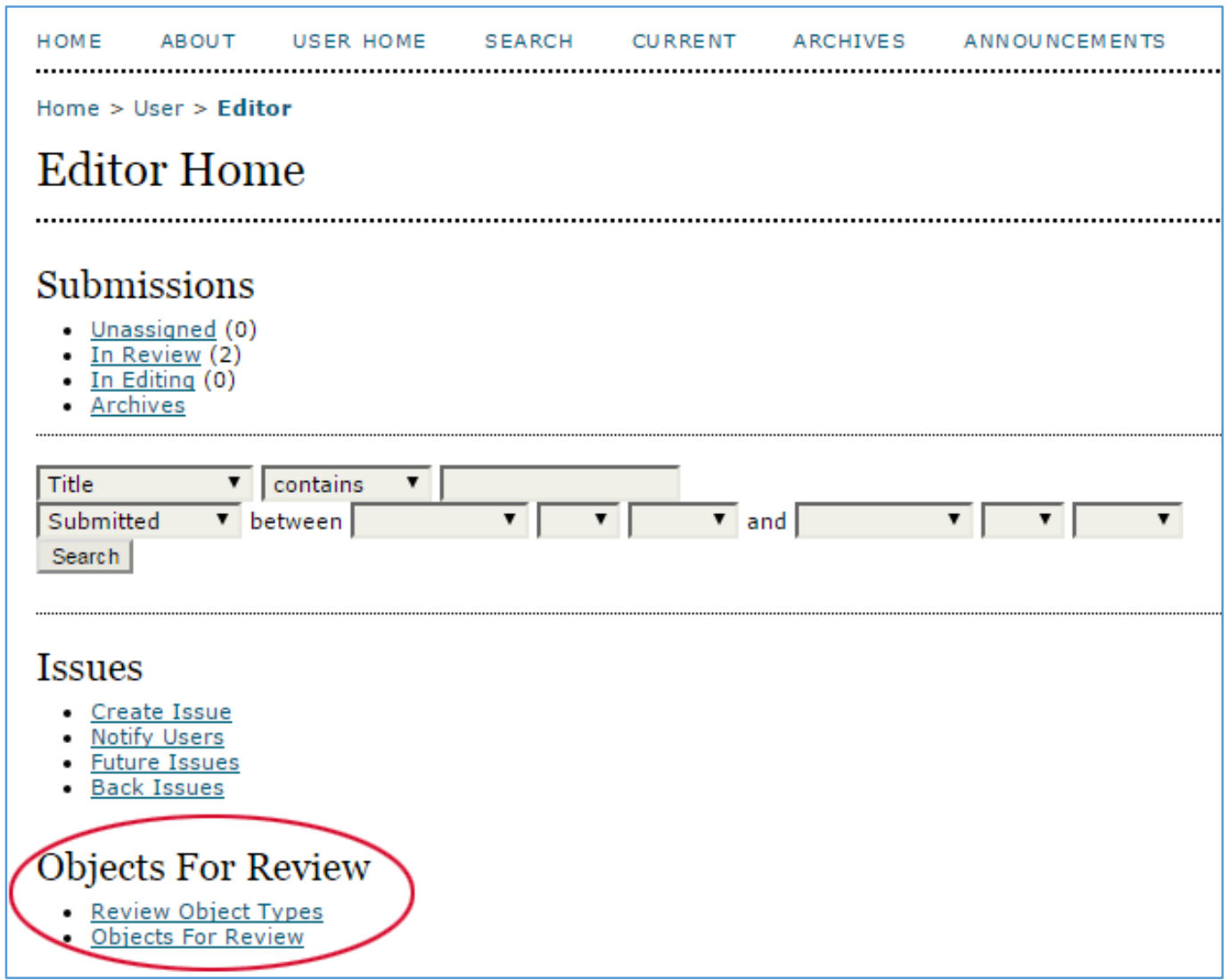

Under 'Review Object Types' kan man indsætte de forskellige materialetyper redaktionen ønsker skal kunne anmeldes (bøger, film, spil etc.), og under 'Object For Review' indsættes de konkrete, udvalgte objekter, der ønskes anmeldt 


\section{Review Object Types}

På siden 'Review Object Types' (Materialetyper) skal du vælge hvilke materialetyper, der skal indgå i anmeldelsessortimentet (bøger, film, blogs etc.) samt hvilke sprogopsætninger de skal indgå i. I eksemplet nedenfor vælges 'book' og 'English'

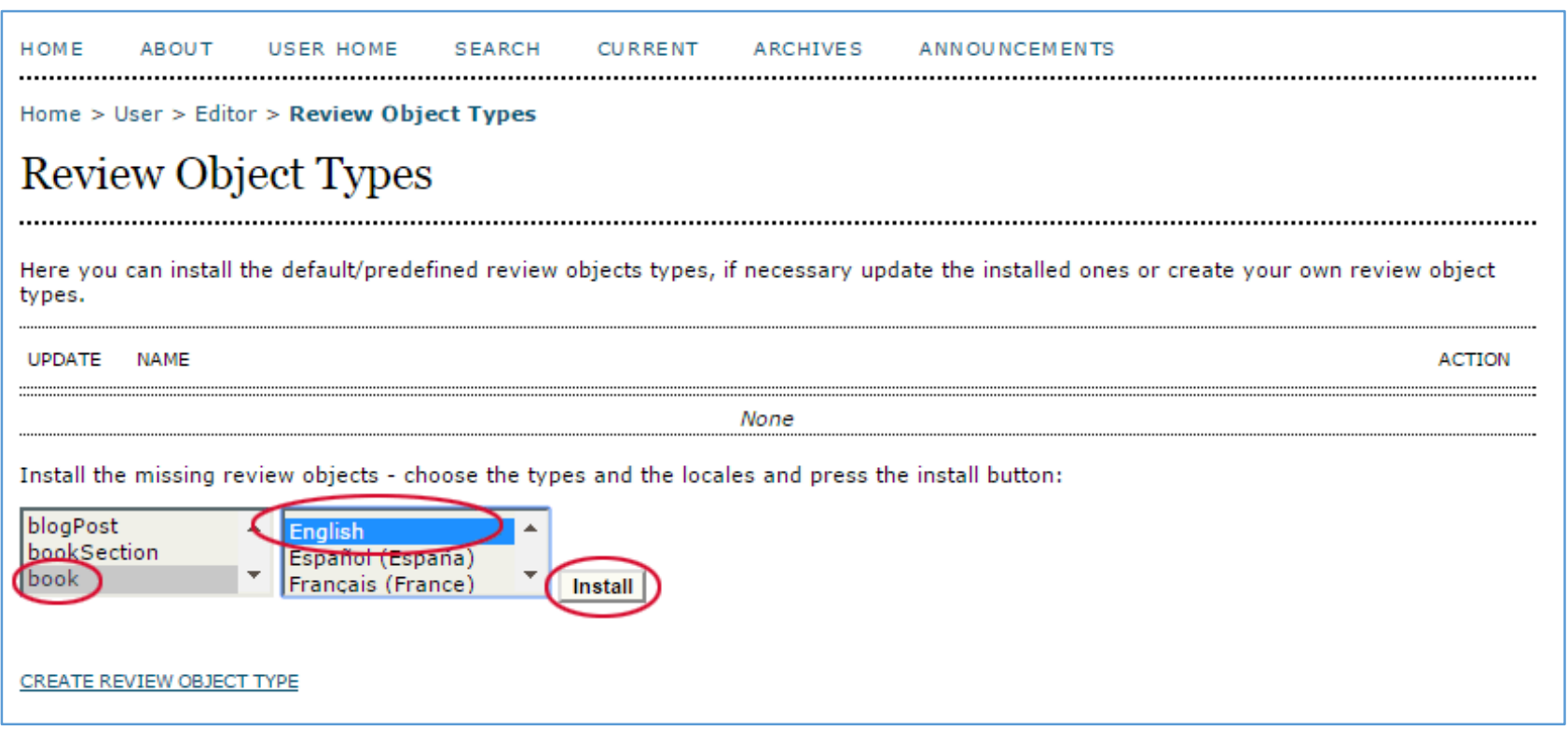

Når materialetypen er indsat har du efterfølgende mulighed for yderligere redigering. F.eks. kan du tilføje en ekstra sprogopsætning (her dansk). Klik dernæst 'Update'

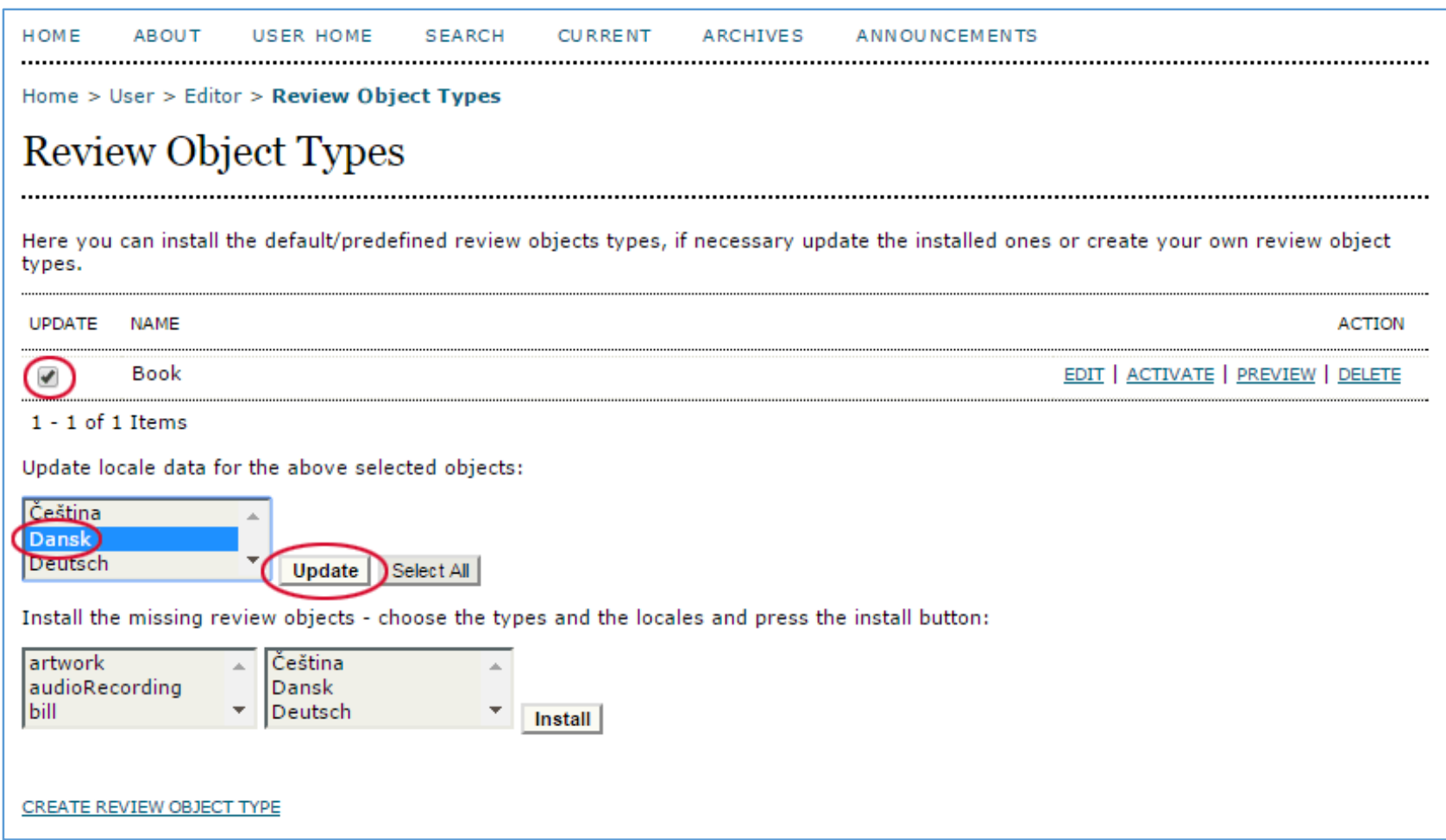


Ved at klikke på linket 'Edit' får du endnu flere redigeringsmuligheder stillet til rådighed

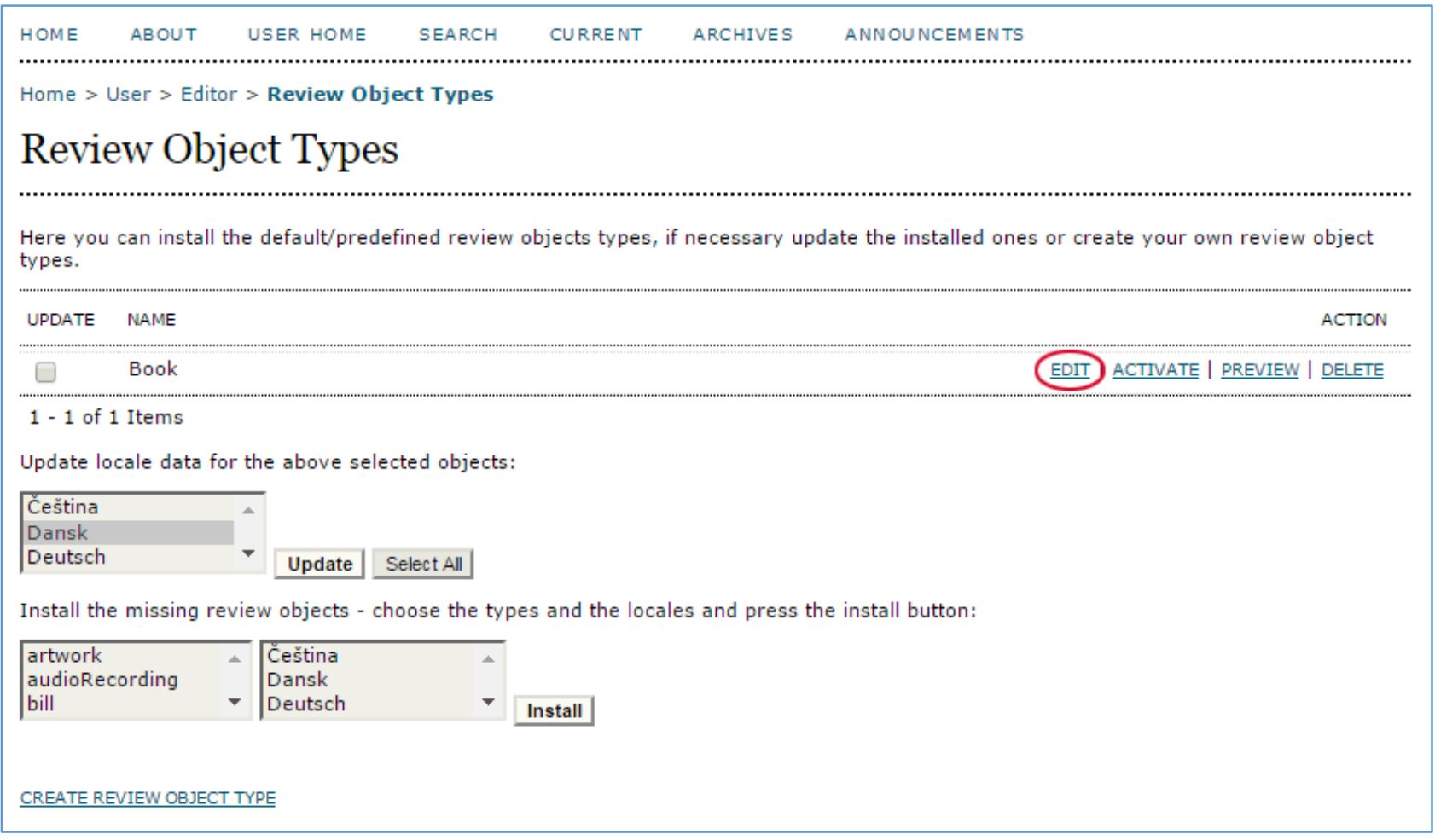

\section{Redigeringssiden ser ud som her:}

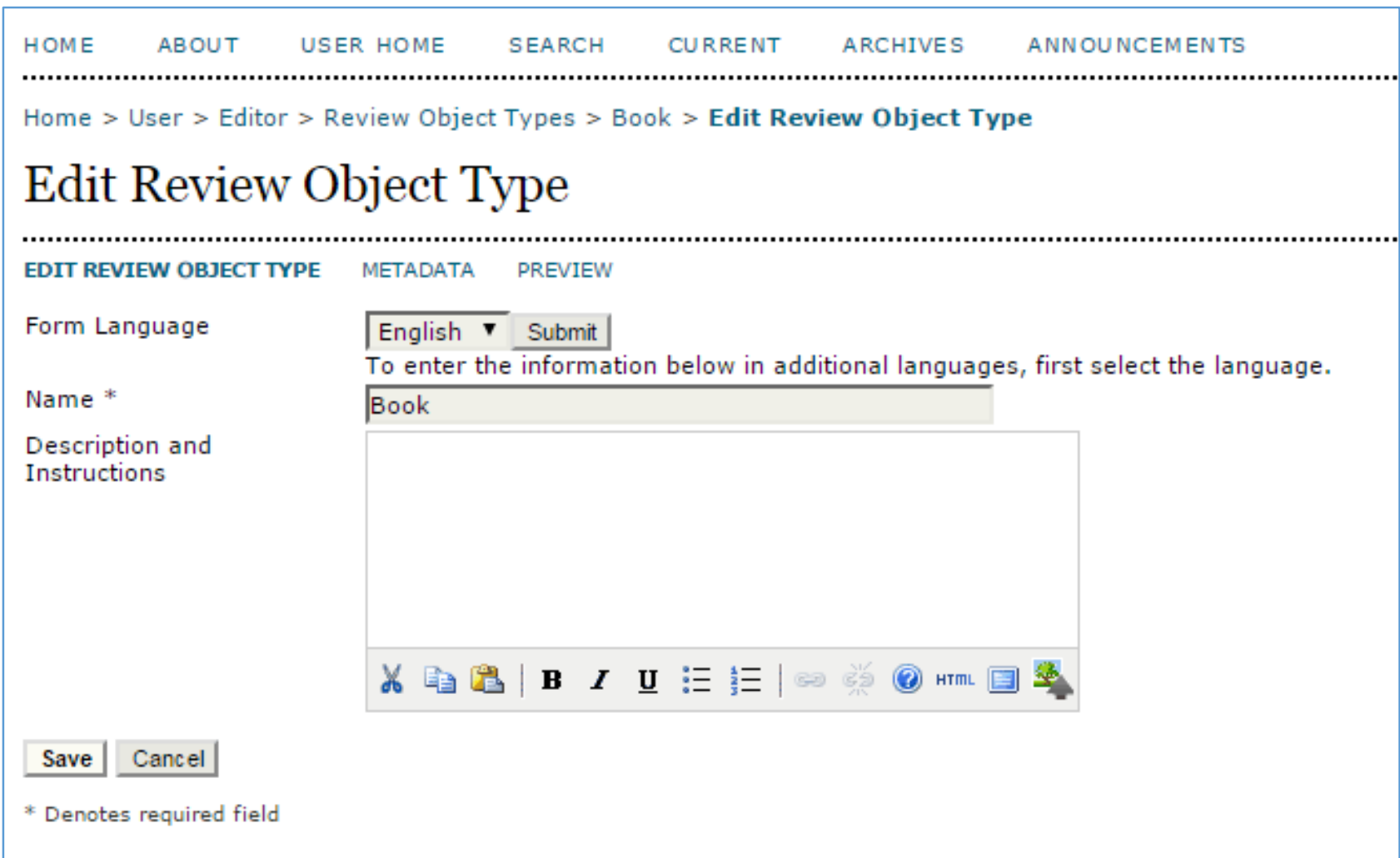


Du kan eksempelvis vælge Dansk i sprogmenuen (1) og i stedet for 'Book' skrive 'Bog' (1). Via linket 'Metadata' (3) kan du yderligere vælge hvilke metadata, der skal indgå ud over de allerede valgte. ${ }^{1}$

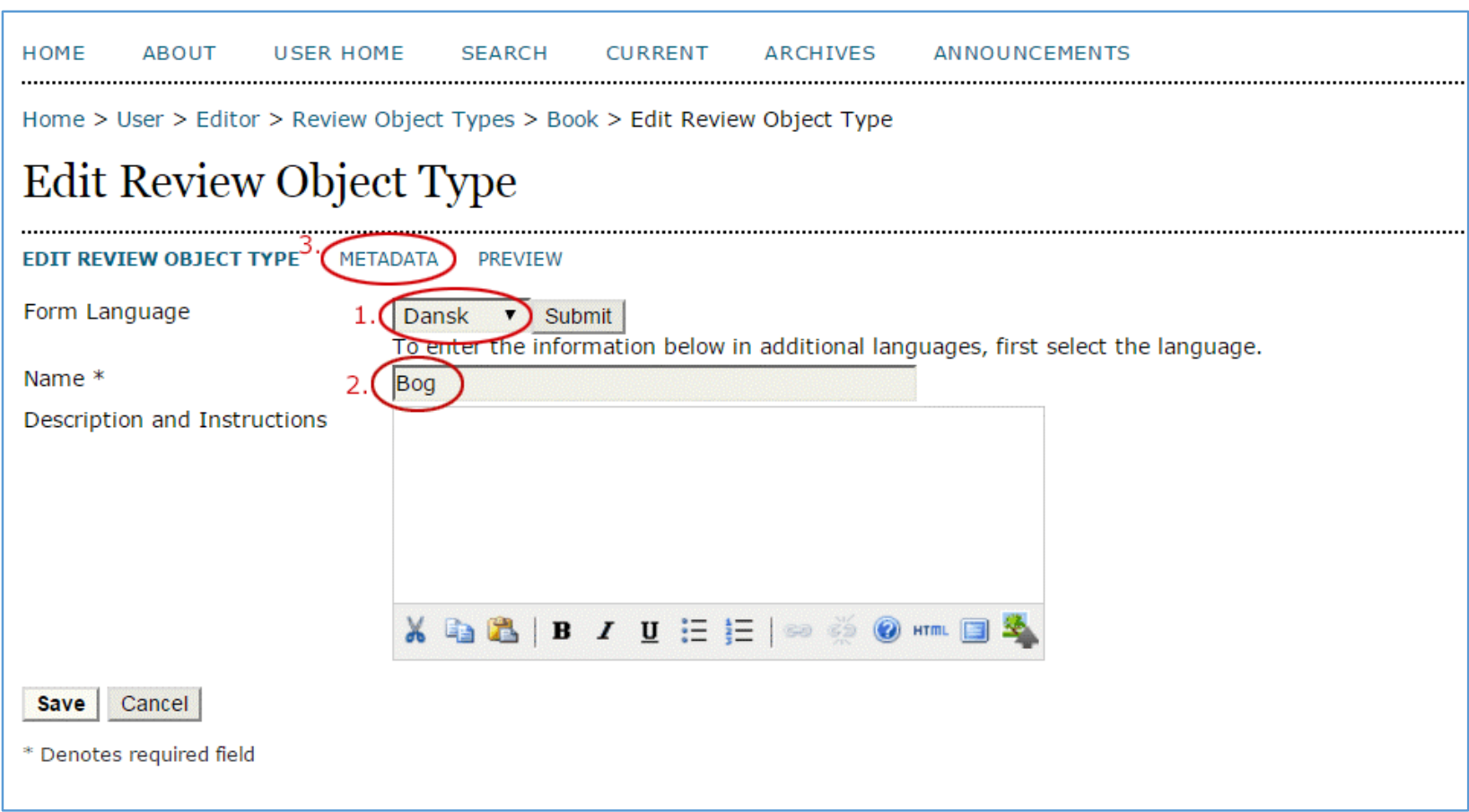

Når alt er, som du ønsker det skal være og klar til at tages i brug, klikker du på linket 'Activate'

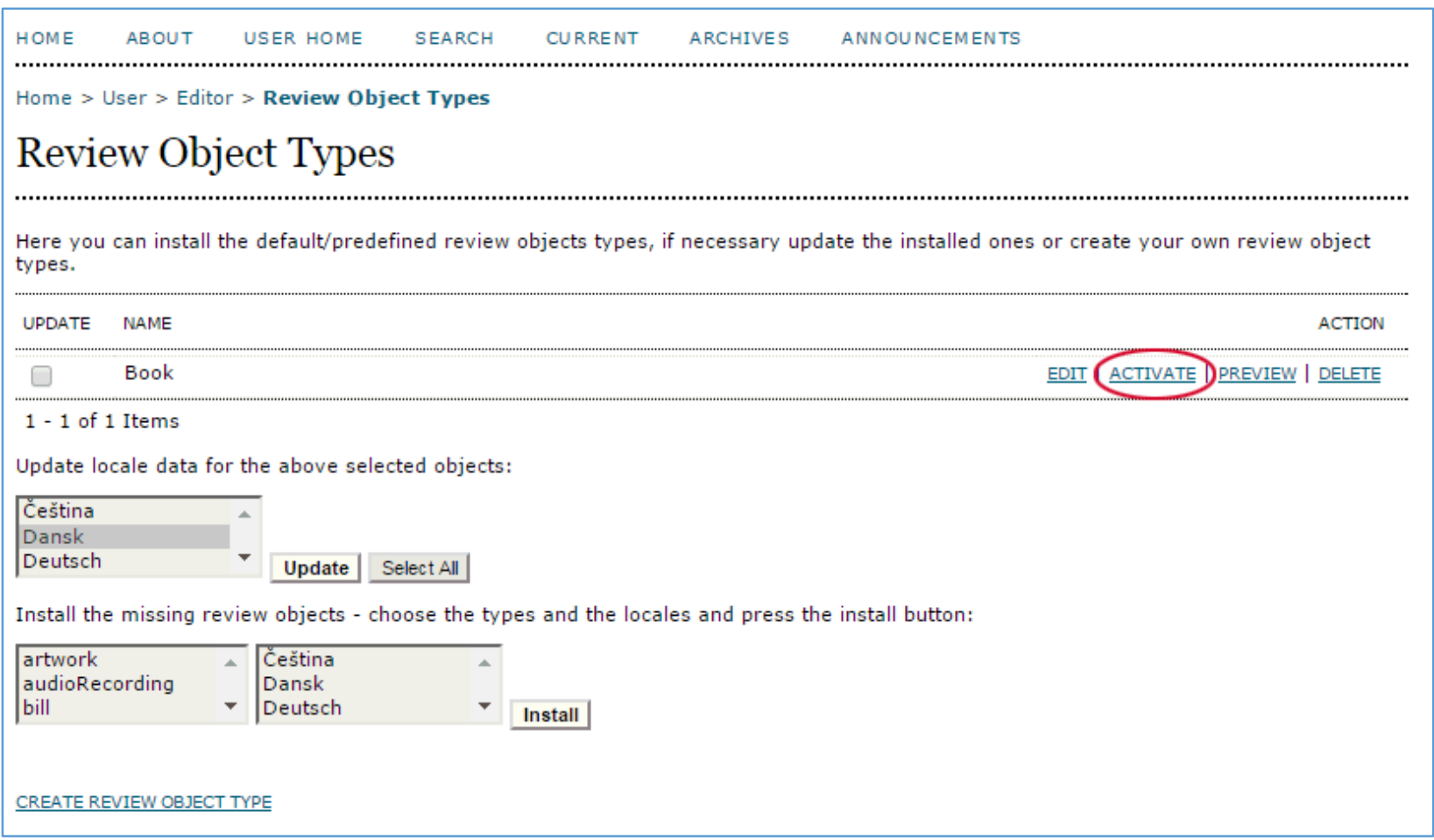

\footnotetext{
${ }^{1}$ I denne opsætning har jeg tilføjet et nyt felt, nemlig 'Object Type', så det fremgår hvilken materialetype, der ønskes anmeldt (se billedet $\varnothing$ verst side 1)
} 
Herefter går du videre til 'Settings'

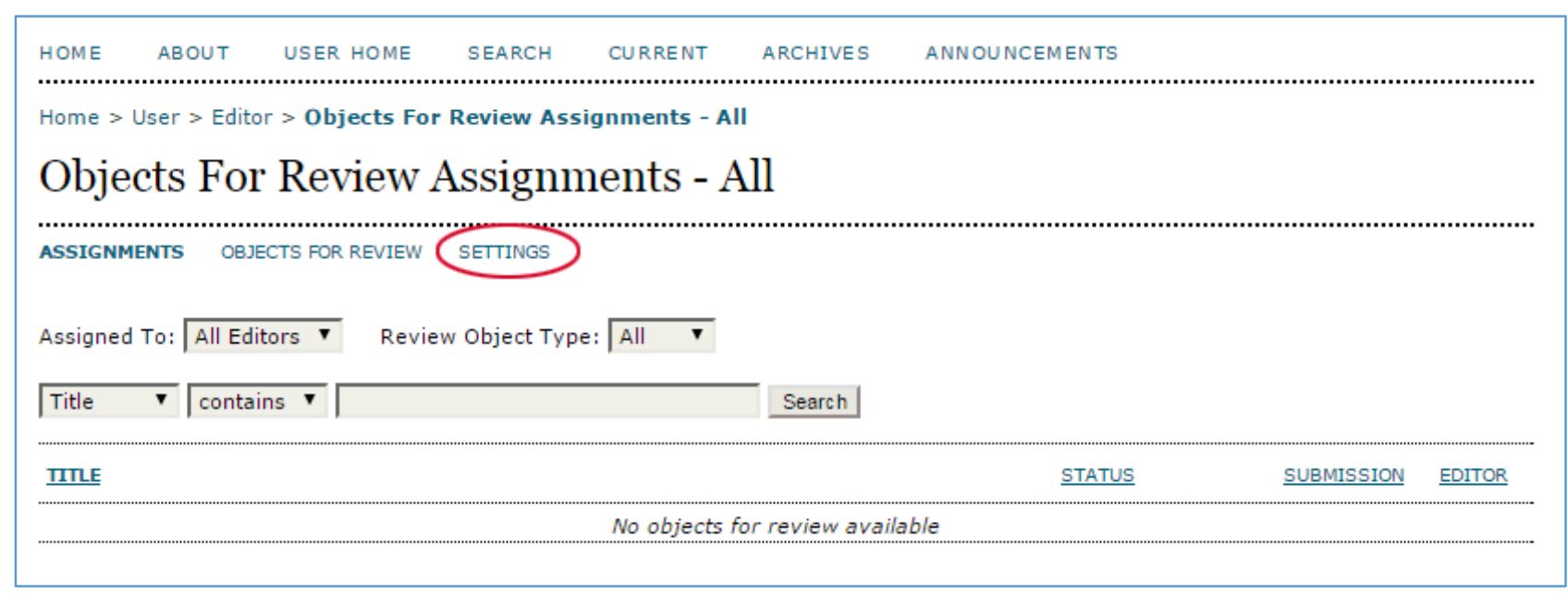


Under 'Settings' kan man vælge mellem to typer opsætning. Her vælger vi den første (Mode 1), da den gør det muligt for forfattere selv at tilmelde sig. I den anden opsætning skal alt foretages af redaktøren, og forfatterne vil ikke kunne se anmeldermaterialet uden først at være blevet kontaktet direkte af redakt $\varnothing r e n$.

Bemærk de forskellige tilvalgsmuligheder. Specielt er det vigtigt at få tilvalgt 'Publish the list of all available objects for review using the navigation item 'Object For Review'. Hvis denne mulighed ikke markeres, kan forfatterne ikke få adgang til de materialer, der skal anmeldes

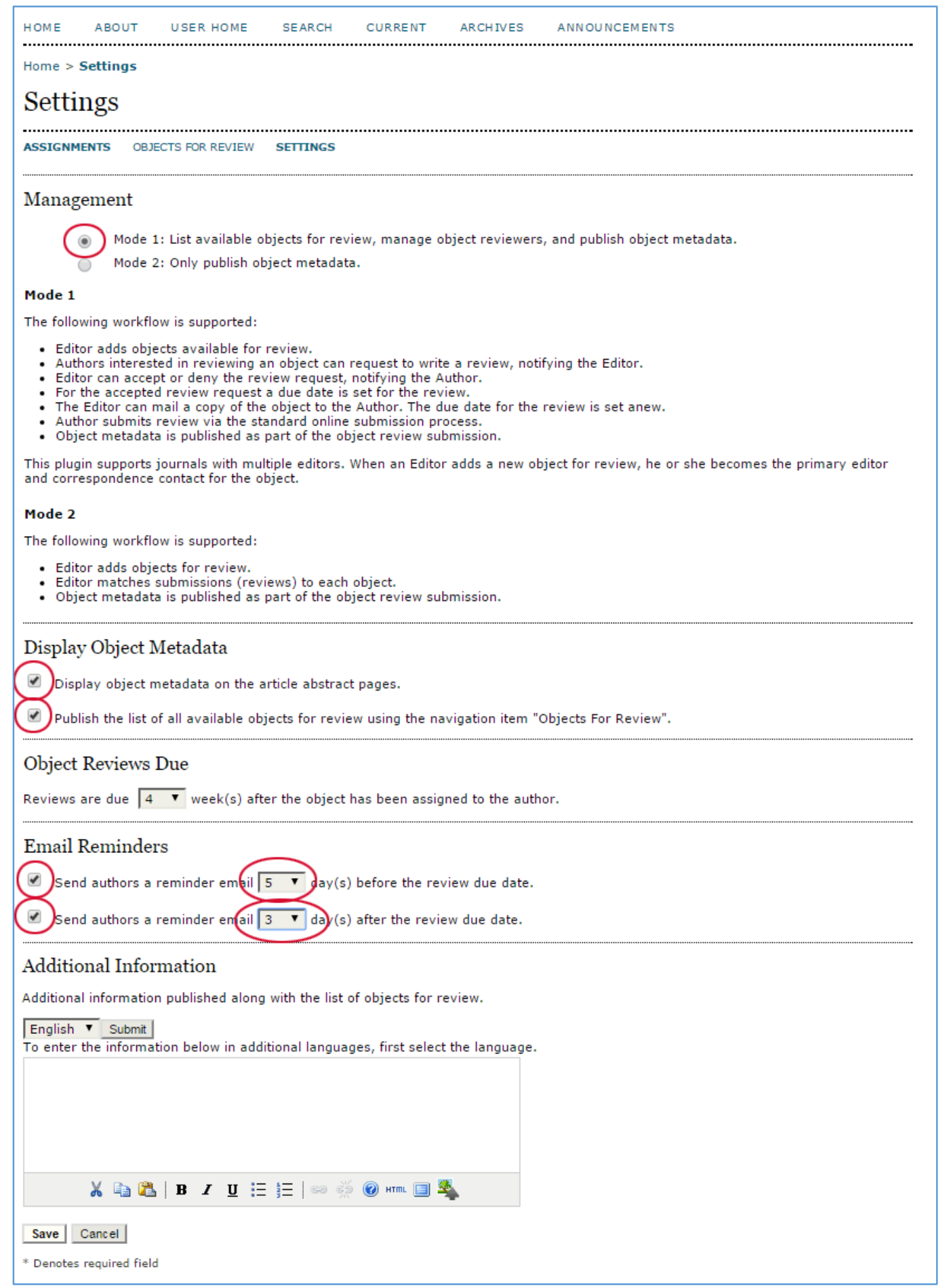




\section{Objects For Review}

Nu skal Editor (redaktøren) så i gang med at lægge materiale ind til anmeldelse. Det sker via linket 'Objects For Review' (Materialer til anmeldelse) (1). Bemærk: Efter at have gemt siden 'Settings' er der nu dukket et nyt topmenu-link op 'Objects For Review' (2). Det er via dette link forfatterne kan nå det materiale, tidsskriftet $\emptyset$ nsker skal anmeldes.

Nederst på siden til venstre vælges hvilken materialetype det drejer sig om. Her har vi valgt at annoncere en bog, vi gerne vil have anmeldt, derfor vælges 'Book' (3) og der klikkes på 'Create' (4).

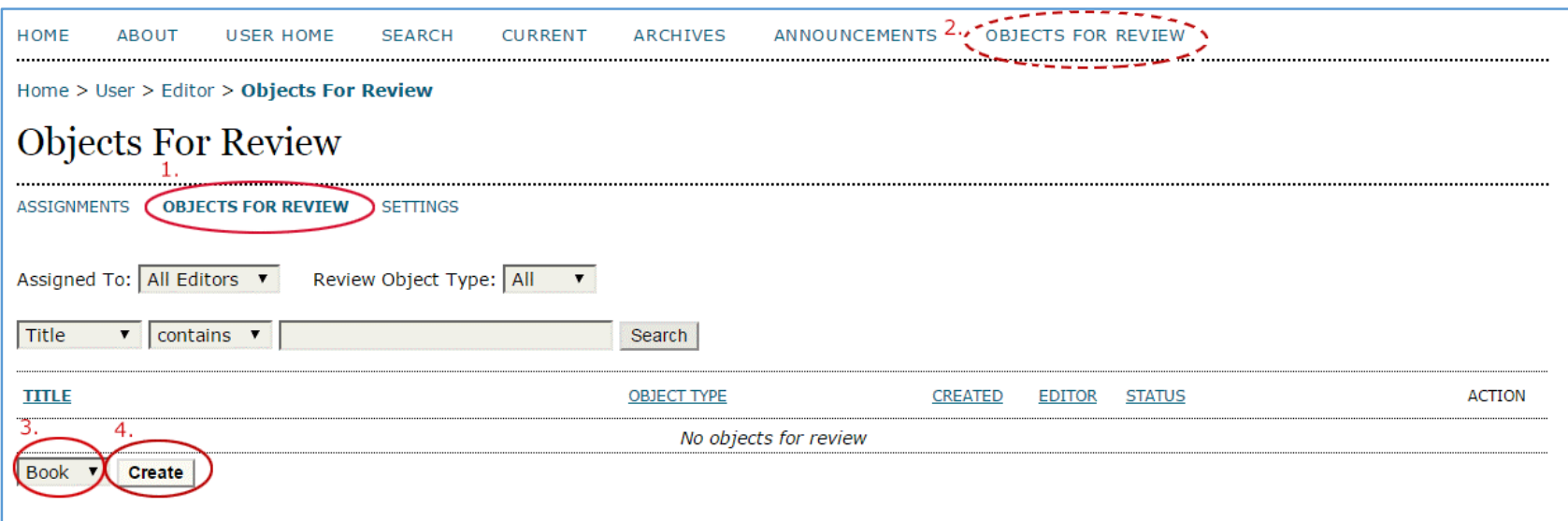


Herefter fremkommer nedenstående side, hvor metadata indskrives. På siden er der også mulighed for at sætte et billede af bogen ind (omslag) (1), ligesom man kan knytte en bestemt redaktør til opgaven (2). Vedkommende skal så stå for kommunikationen med den forfatter, der ender med at skulle stå for anmeldelsen.

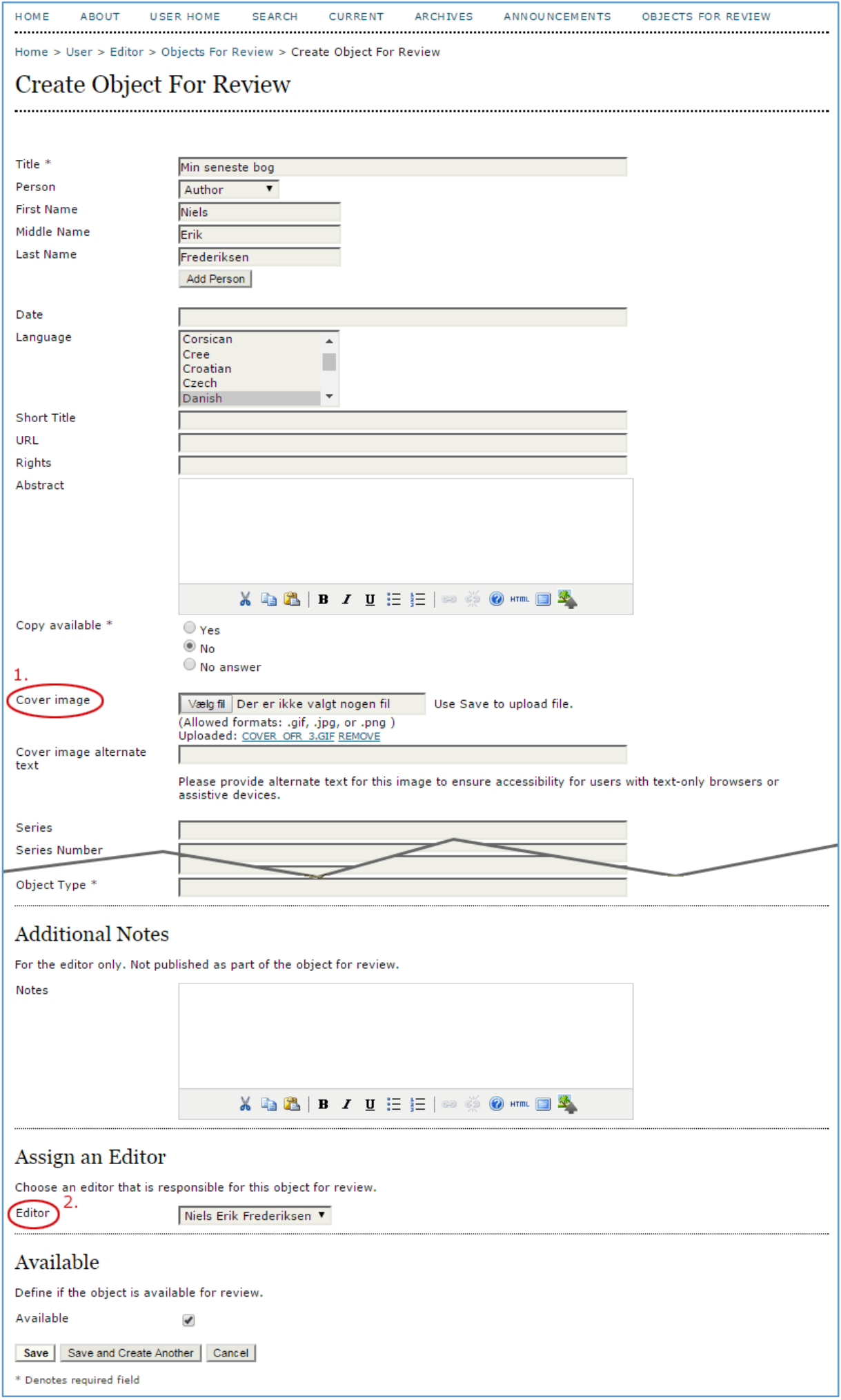


Når siden er udfyldt, og der er klikket 'Save', fremkommer følgende side

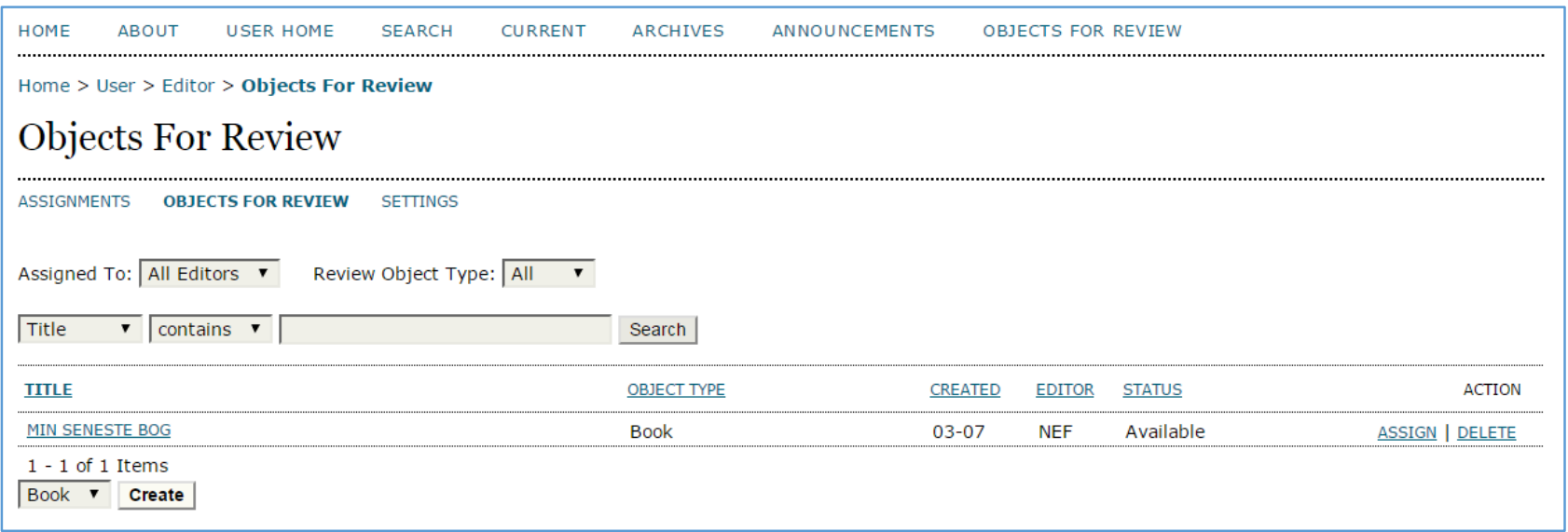

Nu er anmelderopfordringen synliggjort. Læserne vil kunne se det ved at klikke på topmenulinket 'Objects For Review' (Materialer til anmeldelse), og forfatterne vil på samme side kunne give besked om, at de er interesseret $\mathrm{i}$ at foretage en anmeldelse (Request this object for review)

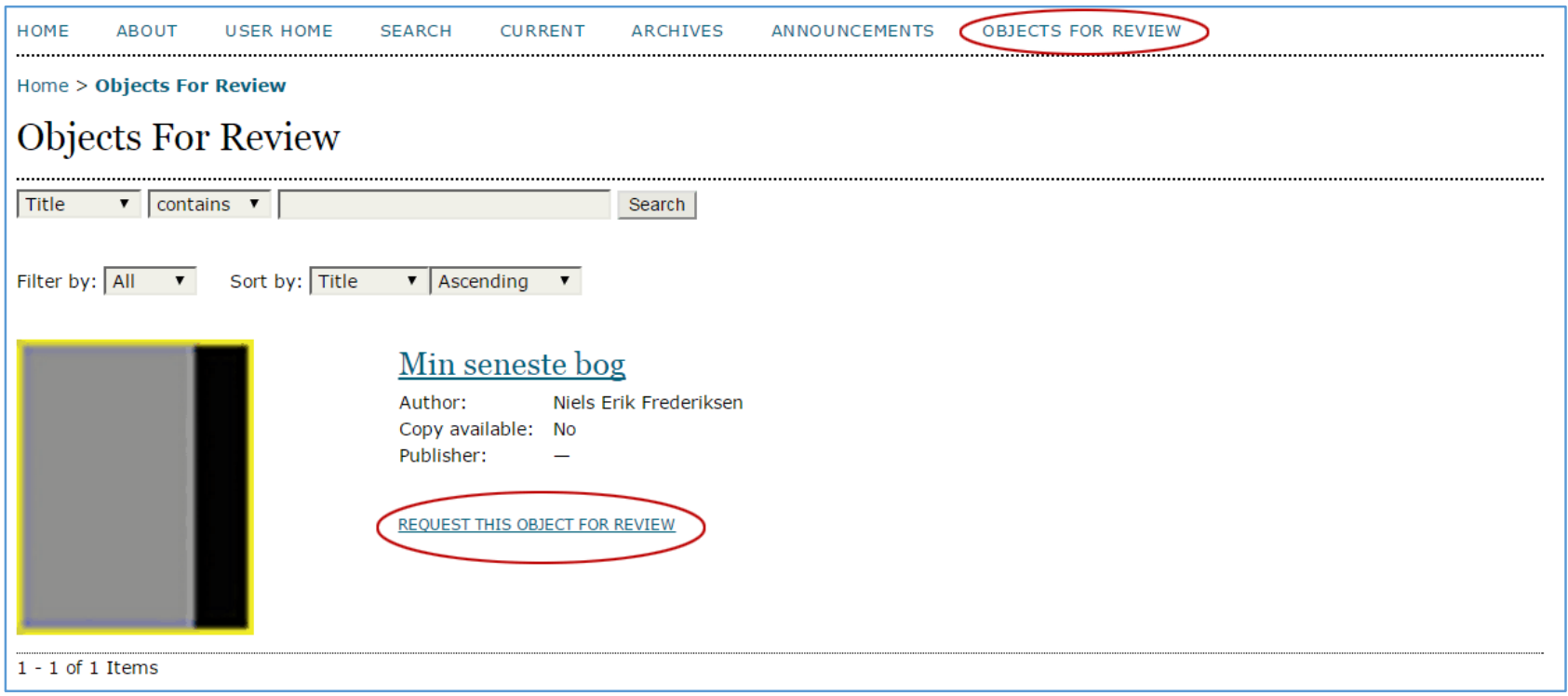


Når forfatteren klikker på linket 'Request this object for review' fremkommer nedenstående mail, som sendes videre til redaktøren.

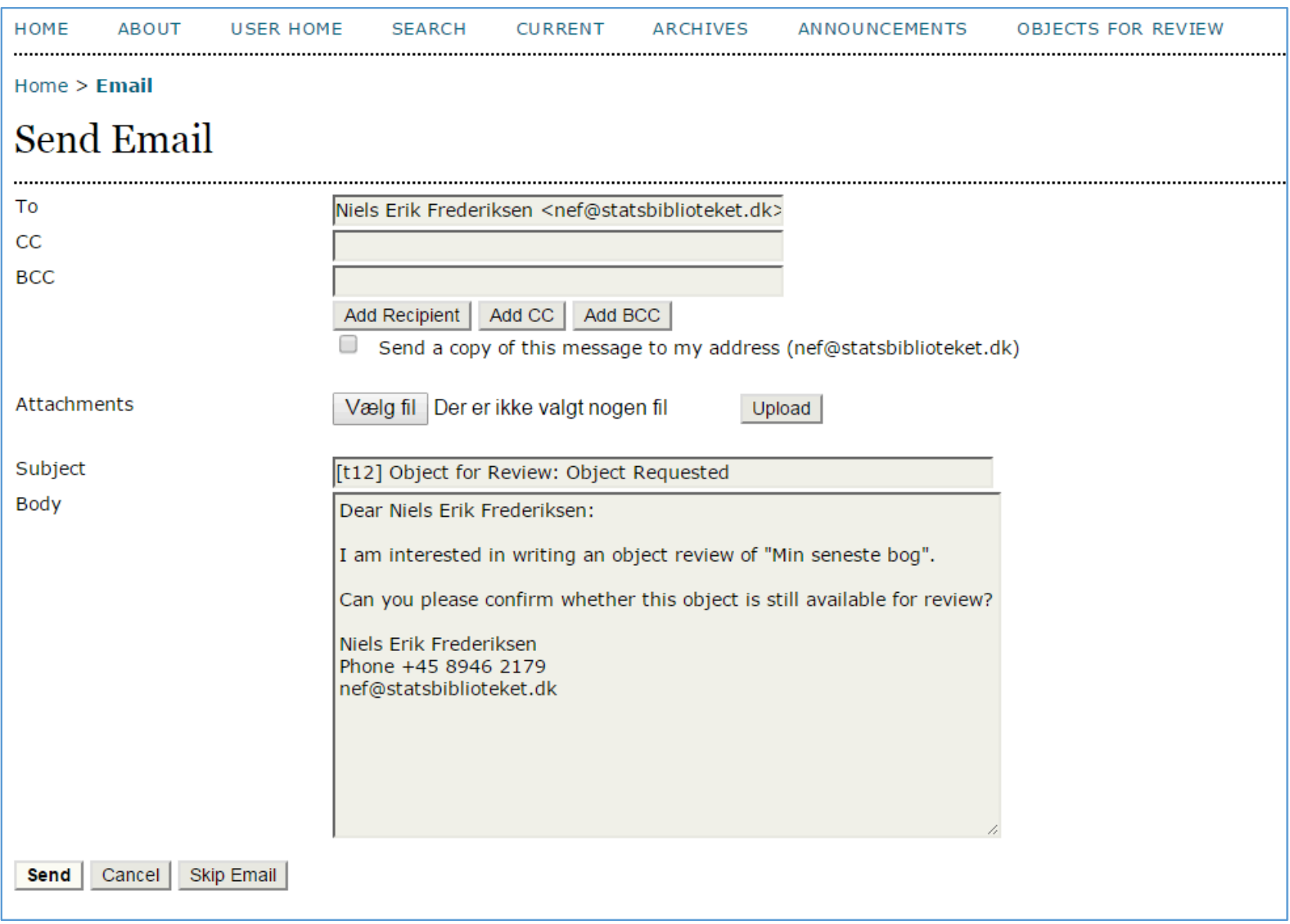

Du har nu som redaktør fået mailbesked, og når du aktiverer linket 'Object For Reviews' på din redaktørstartside fremkommer følgende. Her kan du vælge enten at acceptere eller tilbagevise "ansøgeren". Vi klikker 'Accept'

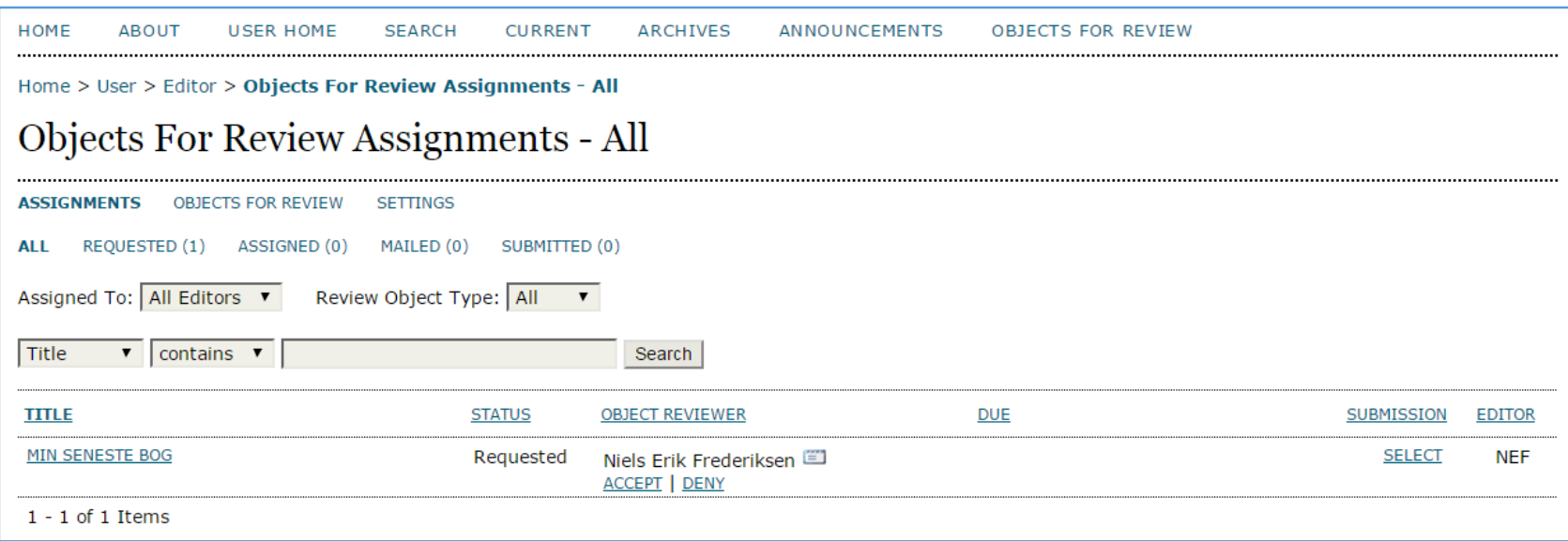


Herved fremkommer følgende mail, der sendes til forfatteren

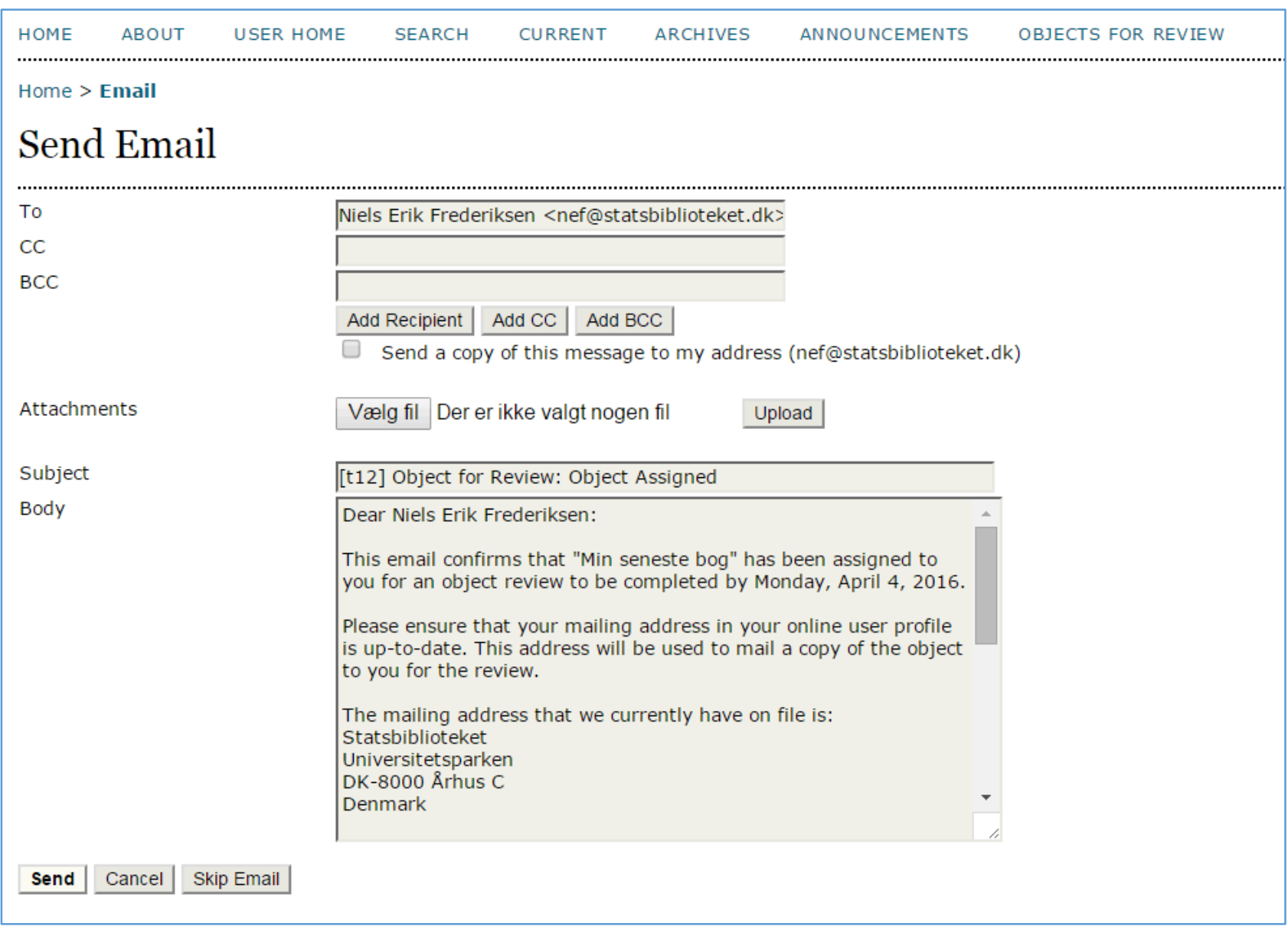

På redaktøren-siden 'Objects For Review Assignments - All' fremgår det, at bogen er sendt til anmeldelse

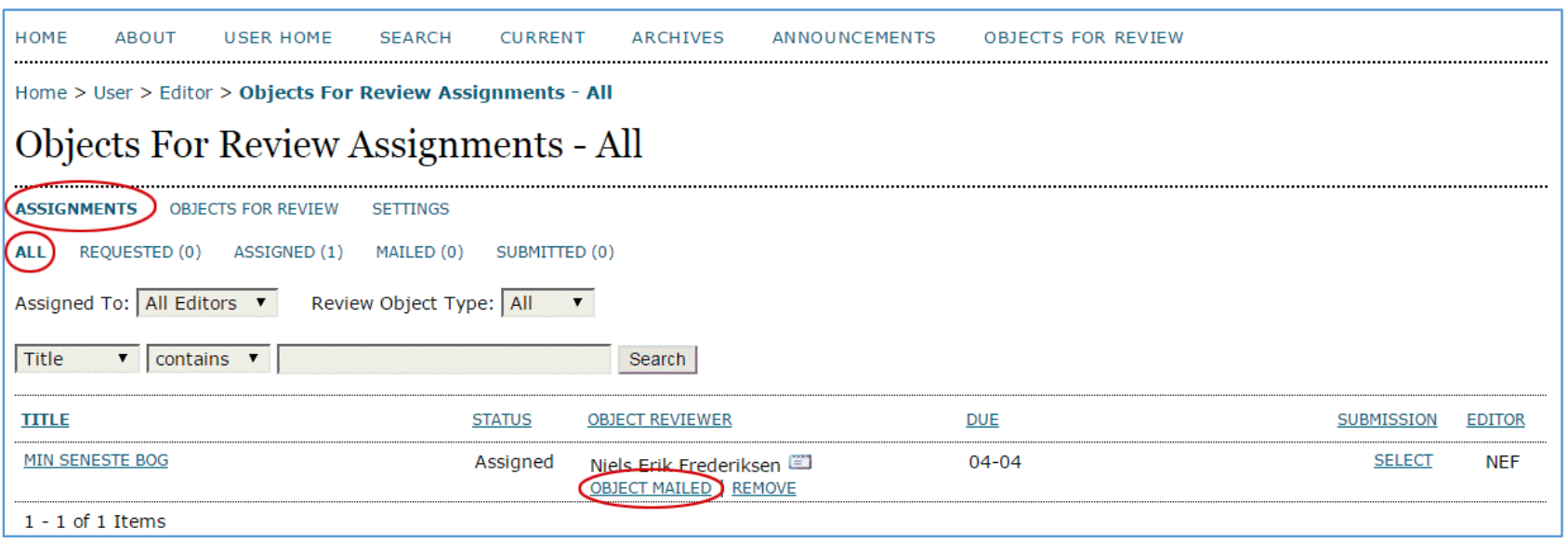


På forfatterens startside er der nu forbindelse til siden via linket 'My Objects' (Mine materialer)

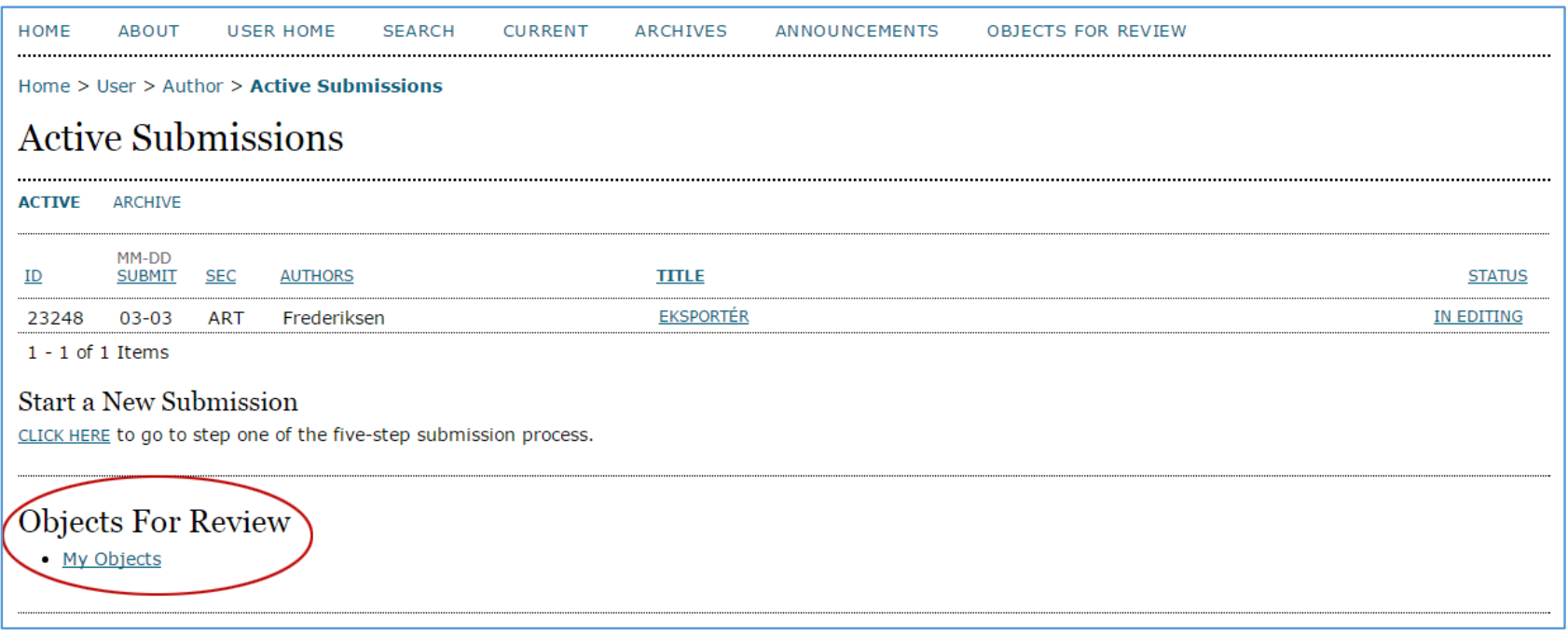

Herfra kan forfatteren, via Submit, sende sin anmeldelse til tidsskriftet. Dette foregår på samme måde, som hvis der var tale om et almindeligt artikel-upload

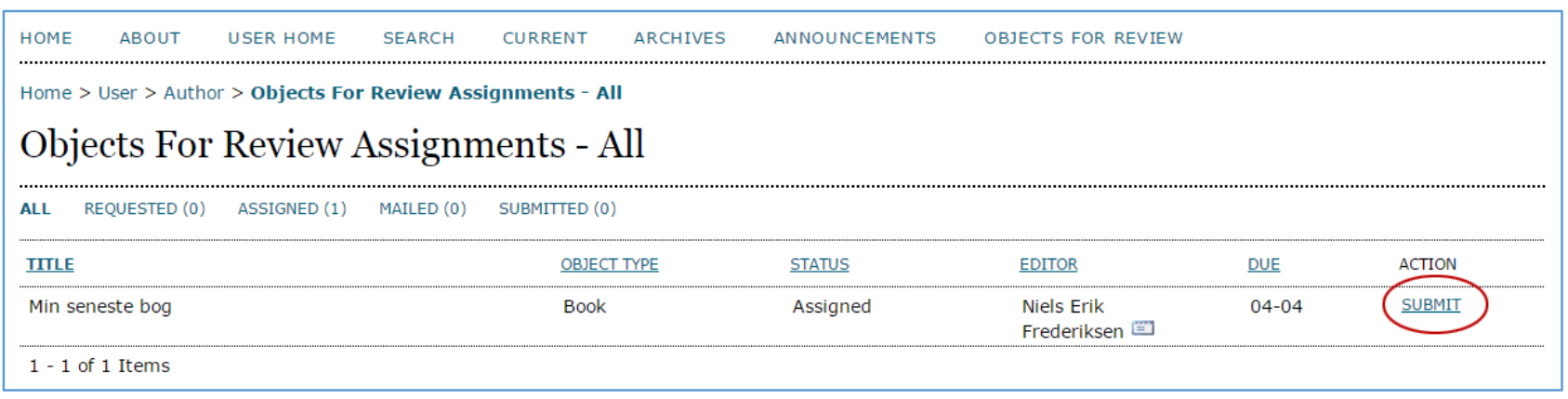


Objects For Review plug-in'en er sat op, så flere har mulighed for at foretage en anmeldelse, men når du, som redakt $\varnothing r$, ikke ønsker flere anmeldelser tilsendt, går du ind på materialets metadataside og fjerner fluebenet ud for 'Available'.

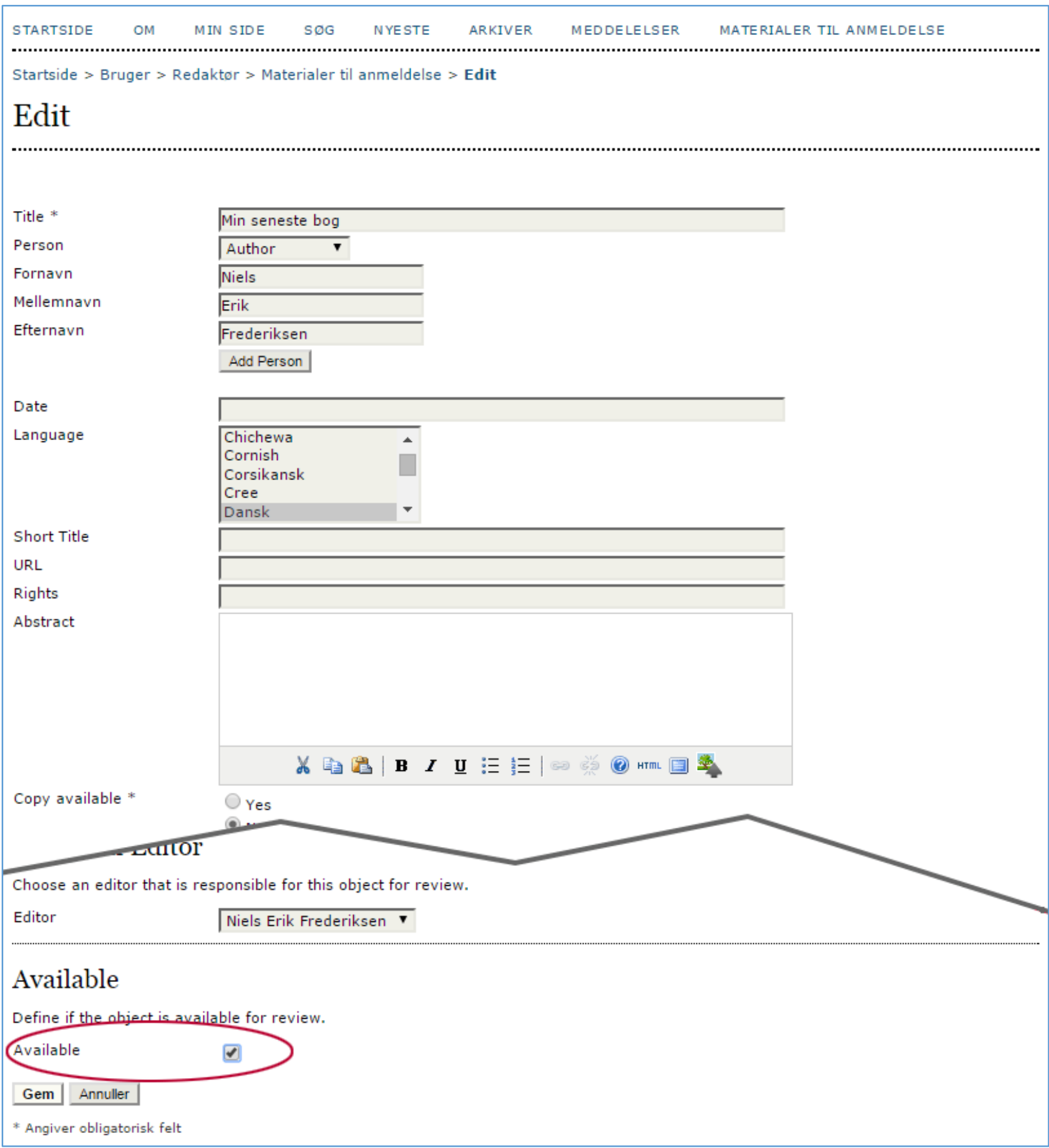

Herefter vil den ikke længere være synlig for tidsskriftets læsere, men materialets informationer og historik vil være gemt. 
Et alternativ - redaktøren vælger selv, hvem han vil opfordre til at forestå bedømmelsen

Hvis du, som redaktør, på forhånd ønsker at få en bestemt person til at stå for anmeldelsen, skal du blot klikke på linket 'Assign' efter at have lavet din 'Object for Review'-side

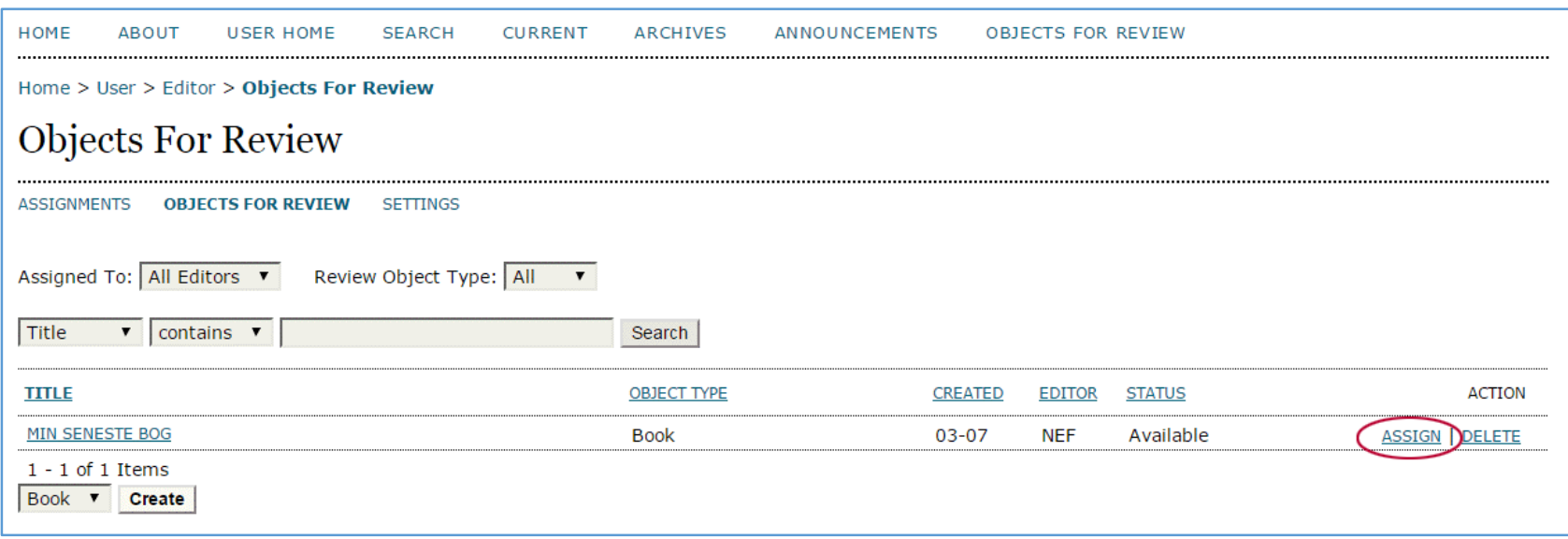

Derved fremkommer listen over tidsskriftets forfattere, og her kan du via et nyt Assign-link vælge den forfatter, du ønsker.

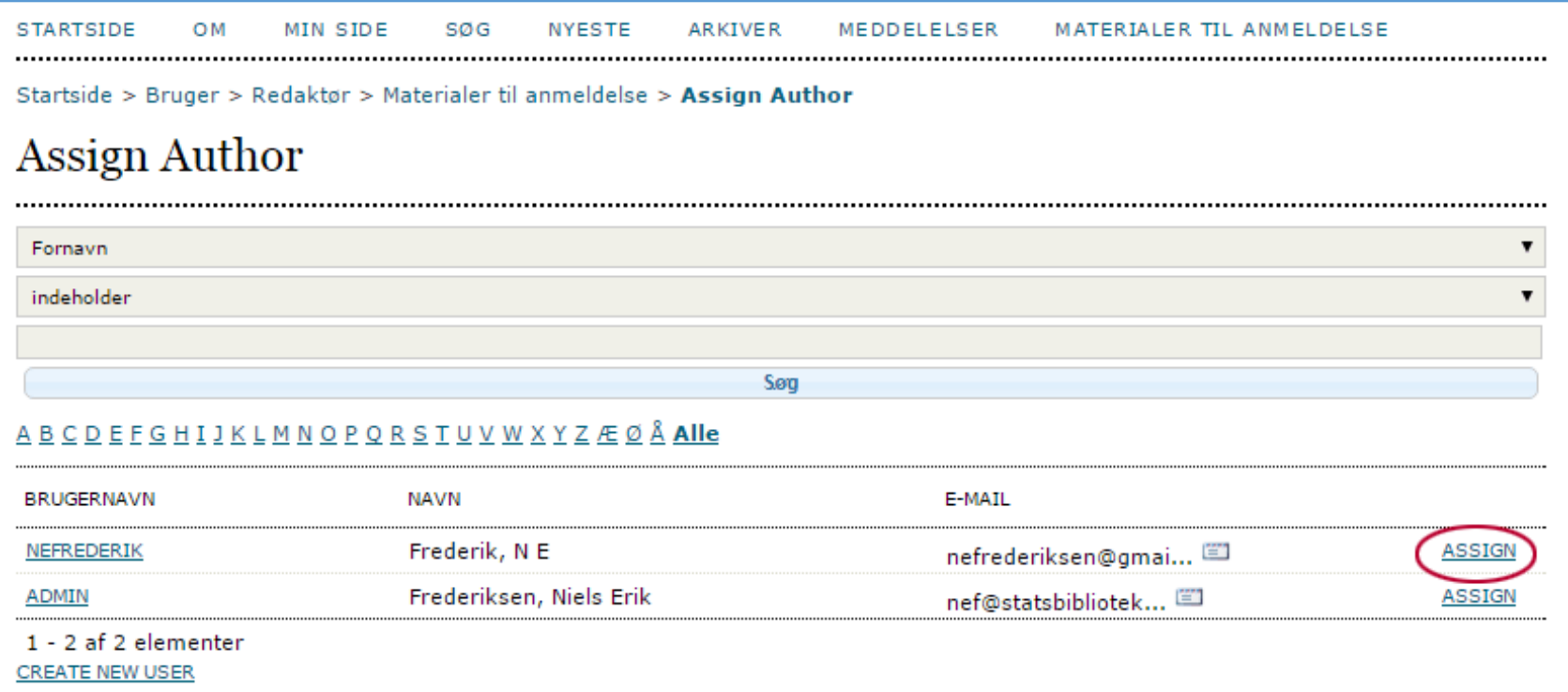

Husk at fjerne fluebenet ud for 'Available' (se ovenfor s. 15) 